\title{
The Demonstration on the Training of Postgraduate Innovative Ability
}

\author{
Xiangsheng Meng \\ School of Economics and Management \\ Hebei University of Technology \\ Tianjin, China \\ e-mail: xshm@hebut.edu.cn
}

\begin{abstract}
Postgraduate innovative ability is an important indicator to measure the level and quality of postgraduate education. Postgraduate innovative ability training process is a complex system process with multi-actor participation and multi-link link. In this paper, we discuss the participation actors, training links and influence factors in the postgraduate innovative ability training process. Measures improving postgraduate innovative ability are also studied. By empirical research, based on the concept of relatively comparison we compare and analyze the factors of postgraduate innovative ability training. Countermeasures and suggestions on postgraduate innovative ability training are put forward.
\end{abstract}

Keywords-postgraduate; innovative ability; influence factor; demonstration

\section{OVERVIEW ON POSTGRADUATE INNOVATIVE ABILITY TRAINING}

Innovation is the essence of economic development. It has a vital role in growth and competitiveness. Innovation was first proposed by Joseph Schumpeter a famous Austrian-American economist in 1912 [1]. Postgraduate innovative ability is an ability or skill using accumulated knowledge capital to do unprecedented innovation activities. It is an important indicator to measure the level and quality of postgraduate education [2]-[4]. Postgraduates are in many cases instrumental in spreading research and teaching on innovation to our country. How to improve the quality of postgraduate education and how to bring up Chinese postgraduate team with strong innovative ability, become the important topic and task for the management of postgraduate education in our country. Therefore, to explore related factors of postgraduate innovative ability training has important theoretical and realistic significance on targeted postgraduate innovative ability training, and implementing constantly improving postgraduate innovative ability.

Postgraduate innovative ability training process is a complex system process with multi-actor participation and multi-link link. In the process of cultivating needs the participation of many actors. Innovation is by its very nature a systemic phenomenon, since it results from continuing interaction between different actors. Using an extensive survey of the relevant literature in [5]-[9], we believe that the actors that take part are student, supervisor, institute, graduate school, university, social demand and social supervision.
In addition to the multiple actors, postgraduate innovative ability training involves many links, roughly divided into: enrollment link, course link, topics choosing link, scientific research and practice link, phase-by-phase examinations link, thesis writing link. They interact each other, and they connect to each other.

Postgraduate intellectual capital refers to all kinds of experience, knowledge and skills, which have been internalized by postgraduate through learning. Once the postgraduate owns intellectual capital, in some ways he possesses innovative ability [10]. The more intellectual capital they have, the stronger innovative ability they have. Postgraduate intellectual capital can be divided into three categories: science-technology form of intellectual capital (encoded information), experience-based form of intellectual capital (tacit knowledge), ideological intellectual capital (idea, postgraduates' innovative sense, consciousness, passion, academic morality, etc.). There are various ways for postgraduate to obtain intellectual capital, such as self-learning, learning by teaching, learning by supervisors' guidance, learning by institute's guidance, learning by various learning methods' combination. Learning is an activity that renders the innovation process cumulative.

In addition, the influence factors of postgraduate innovative ability training are diverse, mainly include: supervisor factor (including supervisor's professional quality, the strength of guidance, scientific research fund, academic atmosphere, sense of responsibility, education idea and so on), institutional factor (including dissertation system, enrollment system, teaching and management system, supporting policies, tutor system, etc.), personal factor (including independent innovative emotion, innovation skill, expression ability, level of knowledge, observation ability, imagination, memory, etc.), innovative practice (including experimental operation ability, social practice ability, the ability of discovering and solving problems, information processing ability), innovation environment (including campus academic environment, social environment, the attention the government paid, national importance, school's awareness, etc.). In this paper, we will explore the relative importance of various factors, which has great significance on postgraduate innovative ability.

Finally, we give several measures improving postgraduate innovative ability training, which contain: stop enrollment expansion, improve admission criteria, and 
select high quality students; increase country's investment, improve postgraduate's studying and living conditions, create favorable environment for postgraduate innovative ability; classified cultivate postgraduate, establish a multiple and scientific postgraduate education training system; perfect the evaluation system, strictly grasp the training goal, and activate postgraduate's education evaluation and elimination mechanism; strengthen supervisor team construction, and construct a supervisor team with high quality and creative ability.

In this paper, we analysis the importance of each actor in the process of postgraduate innovative ability through questionnaire survey, and know the current actual situation. We analyze each training link's relative importance. At the same time, see whether these links process targeted in current cultivation scheme. We investigate postgraduate's attitude towards obtaining different form of intellectual capital; we analyze their evaluation on various factors affecting postgraduate innovative ability. We also study the relative importance of various measures.

\section{RESUlTS AND DisCUSSIONS}

There are 108 valid samples (postgraduates) in this study, in which 40 are in the institute of management, 21 are in the institute of humanity and law, 28 are in the institute of chemical industry, and 19 are in the institute of civil engineering. The questionnaire design use Likerttype scale. We mainly analyze the effect of each actor (supervisor, institute, university, etc.) on innovative ability training process. We discuss the goal of each training link's validity and scientificity, the ways how to access all kinds of intellectual capital. At the same time, we also investigate the influence factors of innovation ability training. We investigate the relative importance of each index by the mean value given by each institute. In the following, if all the four institutes have the same index's sort, we just give the mean sort of the total samples.

\section{A. The main actors of postgraduate innovative ability training}

By the investigation, we can see that, postgraduate thinks that the actors have the following relative importance in the role of innovative ability training process (mean): student (4.71), supervisor (4), institute (3.56), postgraduate school (3.08), university (2.97), social demand and social supervision (2.9). Through the questionnaire survey, it is clear that postgraduate thinks that in addition to self-learning, the other important actor is supervisor's guidance, which has great influence on postgraduate innovative ability training. Supervisor should guide postgraduates to familiar with the latest research techniques and integrated in international research networks.

How about the current actual situation? Through statistics, postgraduate thinks that these actors' present effects on postgraduate innovative ability training are respectively: student (3.88), supervisor (3.79), institute (3.46), postgraduate school (3.6), school (3.43), social demand and social supervision (2.8). The following figure gives the contrast of the two kinds of mean values of actors' role and their present effects on postgraduate innovative ability training (figure 1).

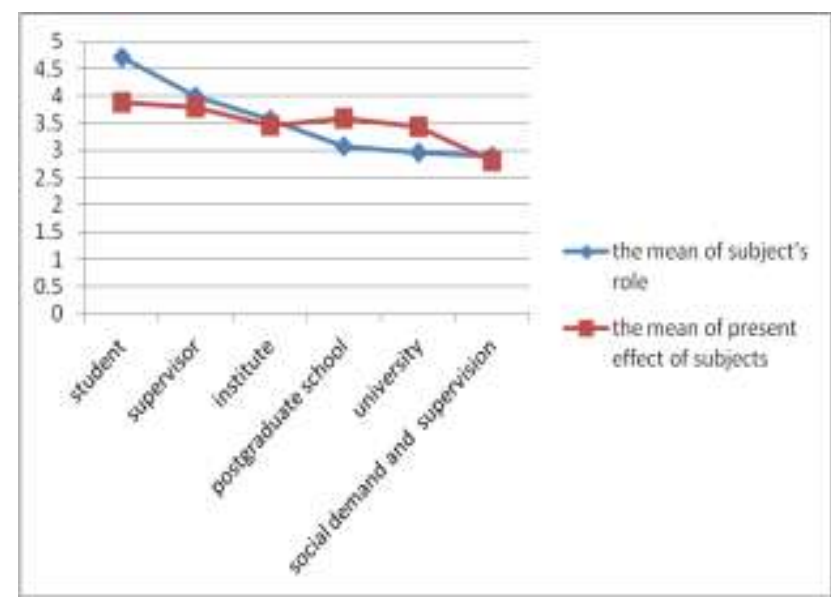

Figure 1. The contrast of two kinds of mean values

Figure 1 shows that, comparing with the effects of other actors on innovative ability training which are given by postgraduate, they think that institute has less effect on the process of innovative ability training. This is worth noting. Institutes should establish more reasonable training plan and concern with ways in which to foster innovation.

\section{B. Postgraduate innovative ability training links}

About the relative importance of each link in the process of innovative ability training, liberal arts' postgraduates and engineering postgraduates have different views (see Table 1).

TABLE I. THE MEAN OF THE RELATIVE IMPORTANCE OF EACH LINK OF EACH INSTITUTE

\begin{tabular}{|l|l|l|l|l|}
\hline institute & $\begin{array}{l}\text { manage- } \\
\text { ment }\end{array}$ & $\begin{array}{l}\text { humanity } \\
\text { and law }\end{array}$ & $\begin{array}{l}\text { chemical } \\
\text { industry's } \\
\text { mean }\end{array}$ & $\begin{array}{l}\text { civil } \\
\text { engineer- } \\
\text { ing's } \\
\text { mean }\end{array}$ \\
\hline $\begin{array}{l}\text { enrollment } \\
\text { link }\end{array}$ & 2.225 & 2.142857 & 2.285714 & 2.368421 \\
\hline course link & 3.525 & 3.904762 & 3.035714 & 3.473684 \\
\hline $\begin{array}{l}\text { topic } \\
\text { choosing } \\
\text { link }\end{array}$ & 3.625 & 3.714286 & 3.821429 & 3.315789 \\
\hline $\begin{array}{l}\text { scientific } \\
\text { research } \\
\text { and } \\
\text { practice } \\
\text { link }\end{array}$ & 4.3 & 4.52381 & 4.571429 & 4.157895 \\
\hline $\begin{array}{l}\text { phase-by- } \\
\text { phase } \\
\text { examinatio } \\
\text { ns link }\end{array}$ & 3.125 & 4 & 3.75 & 3.684211 \\
\hline
\end{tabular}

We can see that postgraduates generally believe that scientific research and practice is the key link in postgraduate innovative ability training. By scientific research and practice link, postgraduates conduct scientific research training to cultivate their scientific innovation ability, creatively transform their knowledge into reality by practice. We need to strengthen this link in the process of postgraduate innovative ability training. For other links, postgraduates in institute of management and humanity and law think that thesis topic choosing link and thesis writing link are two important links in postgraduate 
innovative ability training. However, postgraduates in chemical industry institute and civil engineering institute think that thesis topic choosing link and phase-by-phase examinations link are comparatively important. This reflects different characteristics of the liberal arts and engineering. Enrollment link does not much affect on postgraduate innovative ability training.

Does the current cultivation scheme and process target to these links? Postgraduates generally give the same order of the links as their relative importance order. But the mean of pertinence of each training link is lower than the corresponding mean in table 1 , which requires each actor to develop a more rational and scientific training plan according to postgraduate's individual needs and value orientation.

\section{Ways to access postgraduate intellectual capital}

Figure 2 gives the importance of ways to access different forms of intellectual capital (general mean). It can be seen that, postgraduate thinks that self-learning is the most important way to obtain intellectual capital. Postgraduates accumulate knowledge and professional knowledge by course learning, reading literature, attending academic lectures and reports. In addition, learning by supervisor's guidance is also a relatively important way to access all forms of intellectual capital. We believe, however, relative to the undergraduate study, in the stage of postgraduate training, supervisor's guidance is more of encouraging students to find problems by reading literature than imparting his knowledge and skills to his students. Postgraduates think that learning by various learning methods' combination is important in accessing sciencetechnology and experience-based forms of intellectual capital, but it's not so much important in accessing ideological intellectual capital. They think that the effect of learning by institute's guidance is not obvious. The environmental factors become more important in ideological intellectual capital obtaining.

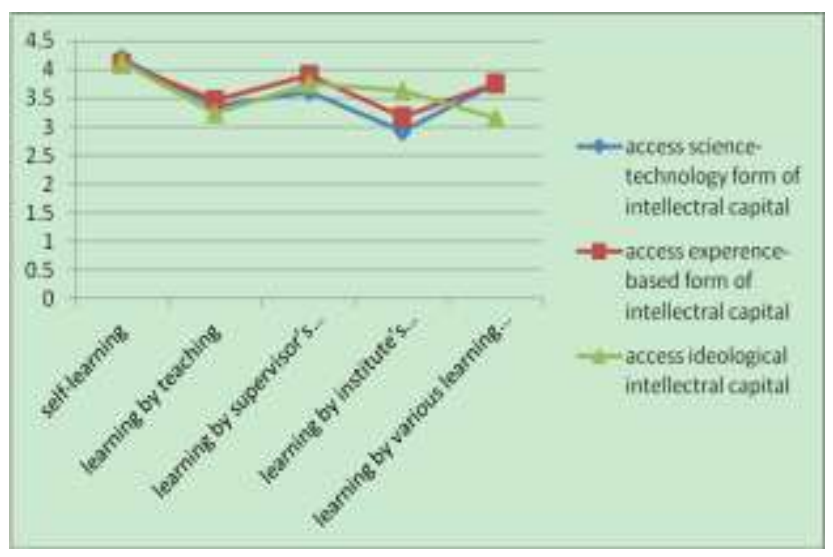

Figure 2. The importance of ways to access different forms of intellectual capital

\section{Influence factors of postgraduate innovative ability training}

According to postgraduates' own experience and understanding, they give their evaluations of influence factors as follows (Table 2), liberal arts' postgraduates and engineering postgraduates have different views.
From Table 2, we can see that, postgraduates in institute of management and humanity and law generally believe that the relatively importance of influence factors of postgraduate innovative ability is personal factor, innovation practice, supervisor factor, innovation environment, institution factor and other factors. However, postgraduates in chemical industry institute believe that the relatively importance of influence factors of postgraduate innovative ability is supervisor factor, innovation practice, innovation environment, personal factor, institution factor and other factors. postgraduates in civil engineering institute believe that the relatively importance of influence factors of postgraduate innovative ability is supervisor factor, personal factor, innovation environment, innovation practice, institution factor and other factors.

\section{TABLE II. THE MEAN OF THE RELATIVE IMPORTANCE OF} INFLUENCE FACTORS

\begin{tabular}{|l|l|l|l|l|}
\hline Factors & $\begin{array}{l}\text { manage- } \\
\text { ment }\end{array}$ & $\begin{array}{l}\text { humanity } \\
\text { and law }\end{array}$ & $\begin{array}{l}\text { chemical } \\
\text { industry's } \\
\text { mean }\end{array}$ & $\begin{array}{l}\text { civil } \\
\text { engineer- } \\
\text { ing's } \\
\text { mean }\end{array}$ \\
\hline $\begin{array}{l}\text { superviso } \\
\text { r factor }\end{array}$ & 4.025 & 4.380952 & 4.392857 & 4.368421 \\
\hline $\begin{array}{l}\text { institution } \\
\text { al factor }\end{array}$ & 3.425 & 3.952381 & 3.642857 & 3.842105 \\
\hline $\begin{array}{l}\text { personal } \\
\text { factor }\end{array}$ & 4.3 & 4.666667 & 4.142857 & 4.157895 \\
\hline $\begin{array}{l}\text { innovatio } \\
\mathrm{n} \text { practice }\end{array}$ & 4.1 & 4.52381 & 4.214286 & 3.842105 \\
\hline $\begin{array}{l}\text { innovatio } \\
\mathrm{n} \text { envir- } \\
\text { onment }\end{array}$ & 3.825 & 4.047619 & 4.321429 & 4.052632 \\
\hline $\begin{array}{l}\text { Other } \\
\text { factors }\end{array}$ & 2.435897 & 2.809524 & 2.964286 & 2.315789 \\
\hline
\end{tabular}

We can see that most postgraduates think that the most important influence factors of innovative ability training are supervisor factor, personal factor and innovation environment. It is an important way to obtain innovative ability through scientific research and practice training. In addition, personal factor is also important. However, postgraduate generally think that the effect of institution factor on postgraduate innovative training is not obvious.

\section{E. Measures improving postgraduate innovative ability training}

Postgraduates generally believe that the relatively importance of the measures improving postgraduate innovative ability training is: stop enrollment expansion, improve admission criteria, and select high quality students (3.84); increase country's investment, improve postgraduate's studying and living conditions, create favorable environment for postgraduate innovative ability (4.06); classified cultivate postgraduate, establish a multiple and scientific postgraduate education training system (4.21); perfect the evaluation system, strictly grasp the training goal, and activate postgraduate's education evaluation and elimination mechanism (3.98); strengthen supervisor team construction, and construct a supervisor team with high quality and creative ability (4.29); other measures (2.95). 
The above statistical findings show that, among these measures, the most important measure is strengthening supervisor team construction; construct a supervisor team with high quality and creative ability. Classified cultivating postgraduate, establishing a multiple and scientific postgraduate education training system is also an important measure. According to different goals and requirements, different system of scientific research and training system should be set up.

\section{THE CONCLUSION}

From the above analysis, we think that the questionnaire survey can basically reflect problems existing in the current process of postgraduate's training and some phenomenon which people universally identify, and can embody postgraduates' some needs and requirements for innovative ability training. Therefore, we think that this investigation is successful. We get the following conclusions by the questionnaire survey:

The postgraduate innovative ability training process is a process with multi-actor participation. In addition to selflearning, the other important actor is supervisor's guidance, which has great influence on postgraduate innovative ability training. Other actors' role in the process of innovative ability training also cannot be ignored. Discipline and the college should play an important role in the process of postgraduate innovative ability.

Postgraduate innovative ability training involves many links. Thesis topic choosing link and thesis writing link are two important links in liberal arts postgraduate innovative ability training. On the other hand, thesis topic choosing link and phase-by-phase examinations link are comparatively important for engineering postgraduate innovative ability training. This reflects the differences between the different disciplines in the science and the differences between professional training. This also reflects different characteristics of the liberal arts and engineering. In the process of postgraduate innovative ability training, targeted training should be given according to actor characteristics. Thesis topic choosing link is part of the scientific research and innovation. Many supervisors choose topics for their students, even though this can save students' time, but this also can kill their exploring interests and innovative thinking.

Every new innovation consists of a new combination of existing ideas, capabilities, skills, resources, etc. It follows logically from this that the greater the variety of these factors postgraduates had, the greater the scope for them to be combined in different ways, producing new innovation which will be both more complex and more sophisticated. Hence, postgraduate intellectual capital is considered essential for innovation. Self-learning and learning by supervisor's guidance are the most important ways to obtain intellectual capital.

The important factors that affect innovative ability training are personal factors, supervisor factor and innovation practice. Obtaining innovative ability by scientific research and practice is the key method. In effect, the present process of postgraduate innovation training is lack of innovation practice. This should be strengthened in the future. Practice is the only way from ideal to reality.
Therefore postgraduates' innovative ability training should lay particular emphasis on the ability of solving practical problems. It can be carried out by adding engineering training and setting up school-run factory.

Strengthening the construction of supervisor team, guiding and training to improving postgraduate innovative ability by supervisor's guidance is an important measure to promote postgraduate innovative ability training. In addition, according to different objectives and requirements, different scientific research and teaching training systems should be set up. Classified cultivating postgraduate is necessary to postgraduate innovative ability training.

Supervisor is an important participant in postgraduate innovative ability training. While improving their own quality, supervisors should allow students to explore, to carry on independent thinking, and focus on cultivating postgraduates' innovative spirit. Postgraduates are trained by leading researchers, and often conversant with emergent research methods and approaches. Such individuals can be carriers of new theoretical insights, new techniques and observations, and new skills. Over time, they will play an important role in innovation to our country.

\section{ACKNOWLEDGMENT}

This research was supported by ZH2011206 and HNSF(A2011202071) of Hebei Province.

\section{REFERENCES}

[1] J. Fagerberg, D.C. Mowery, and R.R. Nelson, The Oxford Handbook of Innovation. Oxford University Press, 2004.

[2] H. Guo, Y. Mao, X. Bai, and Z. Zeng, "A study of the impact of the enterprise on entrepreneurial intention of college student education," Soft Science, vol. 23, 2009, pp. 69-74.

[3] Q.Y. Wu, S.H. Ding, and W. H. Hou. "A study on the impact of college students' personal characteristics on entrepreneurship tendency", Pioneering with Science \& Technology Monthly, vol. 6, 2008, pp. 30-31.

[4] H. Wan and H.H. Zhang. "The connotation and structure of college students' innovation ability--case and empirical study", Journal of National Academy of Education Administration, vol. 2, 2012, pp. 81-86..

[5] J.L. Zhang, "Exploration on graduate cultivation mechanism reform based on innovative ability," China Higher Education Research, vol. 3, 2008, pp. 34-38.

[6] A.B. Xie, "Cultivate doctoral students' innovative ability combining with a variety of channels," China Higher Education, vol. 20, 2007, pp. 33-35.

[7] C. Sun, "Research on the feature analysis of the innovative ability of graduate students," Journal of Higher Education, vol. 8, 2005, pp. 62-65.

[8] B. Huang, Y.Q. Ding, and D.S. Luo, "The analysis on graduate students' innovative ability," Journal of Jiangsu Polytechnic University, vol. 9, 2008, pp. 67-69

[9] L. Pan, S.M. Ji, and C.D. Lu, "The cultivation of creative talents based on the innovation education platform," Heilongjiang Researches on Higher Education, vol. 143, 2006, pp. 124-126.

[10] H.Z. Ye and N. Ding, "The graduate student innovation ability training strategy based on tacit knowledge," China Higher Education Research, vol. 1, 2008, pp. 132-135. 